\title{
UJI KETAHANAN TIGA VARIETAS TOMAT (SOLANUM LYCOPERSICUM L.) TERHADAP SERANGAN CMV (CUCUMBER MOSAIC VIRUS) DENGAN METODE DAS-ELISA
}

\author{
Lia Agturani Tudaryati ${ }^{1}$, Febi Nurilmala ${ }^{1}$ dan Krisna Dwiharniati ${ }^{2}$ \\ ${ }^{1}$ FMIPA Univeritas Nusa Bangsa, ${ }^{2}$ Akademi Kimia Analis \\ ${ }^{1}$ Jl. K. H. Sholeh Iskandar, Cimanggu, Tanah Sareal-Bogor 1616 \\ 1e-mail : nusabangsa@unb.ac.id
}

\begin{abstract}
Endurance Test Three Tomato Variety (Solanum lycopersicum L.) Against Attacks CMV (Cucumber Mosaic Virus) DAS-ELISA Method

Tomato plantation intensification can be done by controlling nuisance organism plant causes disease in tomato, such as CMV. CMV can be transmitted mechanically, and therefore testing of tomato varieties resistance to $C M V$ can be performed with CMV isolates infect mechanically to healthy tomato plants (variety Marta F1, San Marino, and Viccario). CMV isolates derived from two sources, namely a positive tomato plants attacked by $C M V$ (plant sap) and the positive control CMV AGDIA producers commonly used as a positive control test DASELISA (Double Antibody Sandwich-Enzyme Linked immunosorbent assay). This study aims to test three varieties of tomato resistance against CMV attacks. Research conducted in the screen house and laboratory virology Central Agricultural Quarantine Standards Test. Identification of CMV infection was done by observing the incubation period, symptoms appeared, and continued with DAS-ELISA test. Structured treatment completely randomized design (CRD) with 6 replications. Data processed with fingerprint analysis and continued with various multiple Duncan test at 5\% level test. The results showed the disease symptoms appeared only on the varieties of San Marino from CMV infected plant sap. Symptoms caused a reduction of leaf rolling and leaf lamina 8-10 day incubation period and symptoms of stunted stems with 14-28 day incubation period, the San Marino CMV causes the reduction of plant height by 33\%. Sensitivity of tomato varieties against CMV San Marino sap from plants was quantitatively evidenced by positive results on the DAS-ELISA test. Meanwhile, F1 and Marta varieties resistant to Viccario CMV infection sap from plants and the positive control CMV AGDIA producers.

Keywords : Tomato (Solanum Lycopersicum l.), Cucumber Mosaic Virus, DAS-ELISA method

\begin{abstract}
ABSTRAK
Intensifikasi perkebunan tomat dapat dilakukan dengan mengendalikan organisme pengganggu tanaman (OPT) penyebab penyakit pada tomat, seperti CMV. CMV dapat ditularkan secara mekanis, oleh karena itu pengujian ketahanan varietas tomat terhadap CMV dapat dilakukan dengan menularkan isolat CMV secara mekanik kepada tanaman tomat sehat (varietas Marta F1, San Marino, dan Viccario). Isolat CMV berasal dari dua sumber, yaitu tanaman tomat yang positif terserang CMV (sap tanaman) dan kontrol positif CMV produsen AGDIA yang biasa digunakan sebagai kontrol positif pengujian DAS-ELISA (Double Antibody SandwichEnzyme Linked Immunosorbent assay). Penelitian ini bertujuan untuk menguji ketahanan tiga varietas tomat terhadap serangan CMV. Penelitian dilaksanakan di screen house dan laboratorium virologi Balai Besar Uji Standar Karantina Pertanian pada bulan Januari sampai April 2008. Identifikasi hasil penularan CMV dilakukan dengan mengamati periode inkubasi, gejala yang muncul, dan dilanjutkan dengan pengujian DAS-ELISA. Perlakuan disusun dengan rancangan acak lengkap (RAL) dengan 6 ulangan. Data diolah dengan analisis sidik ragam dan dilanjutkan dengan uji berganda Duncan pada taraf uji 5\%. Hasil penelitian menunjukkan gejala penyakit hanya muncul pada varietas San Marino yang ditulari CMV asal sap tanaman. Gejala yang ditimbulkan berupa daun menggulung dan reduksi lamina daun dengan masa inkubasi 8-10 hari, serta gejala batang kerdil dengan masa inkubasi 14-28 hari, CMV pada San Marino menyebabkan reduksi tinggi tanaman sebesar $33 \%$. Kesensitifan tomat varietas San Marino terhadap CMV asal sap tanaman secara kuantitatif dibuktikan dengan hasil yang positif pada pengujian DAS-ELISA. Sedangkan, varietas Marta F1 dan Viccario tahan terhadap penularan CMV asal sap tanaman maupun kontrol positif CMV produsen AGDIA.
\end{abstract}

Kata kunci : Tomat (Solanum lycopersicum L.), Cucumber Mosaic Virus, metode DAS-ELISA 


\section{PENDAHULUAN}

Tanaman tomat merupakan salah satu komoditas hortikultura yang sangat potensial untuk dikembangkan, karena mempunyai nilai ekonomis cukup tinggi dan potensi ekspornya juga sangat besar. Selain itu, tomat adalah salah satu jenis sayuran yang banyak digemari orang karena rasanya yang enak dan segar serta sebagai sumber vitamin.

Usaha peningkatan produksi dan mutu hasil produksi untuk memenuhi kebutuhan nasional dan ekspor menghadapi beberapa kendala. Kurangnya bibit unggul bermutu tinggi, besarnya biaya produksi seperti penggunaan pestisida dan pupuk yang berlebihan, dan gangguan organisme pengganggu tumbuhan (OPT) merupakan sebagian dari kendala - kendala dalam usaha tersebut. Kendala biologis yang diakibatkan oleh serangan virus pada tomat masih merupakan penyebab utama kegagalan atau rendahnya panen yang didapat petani. Virus sangat sulit dikendalikan, karena virus hidup sebagai parasit obligat di dalam sel tanaman, sehingga usaha untuk mematikan virus hanya bisa dilakukan dengan mematikan sel atau jaringan tanaman inangnya.

CMV (Cucumber Mosaic Virus) pertama kali dilaporkan pada tahun 1916 sebagai salah satu penyebab penyakit tanaman (Doolitle, 1996). Sampai saat ini belum ada pestisida yang efektif untuk mengendalikan virus atau serangga vektornya, satu - satunya cara adalah penggunaan kultivar tomat yang tahan/resisten terhadap virus.

CMV bersifat terbawa benih (seedborn), dapat ditularkan dari induk ke keturunannya, secara mekanik, maupun melalui serangga vektor seperti kutu daun Myzus persicae (CABI, 2006). Gejala yang ditimbulkan CMV berbeda - beda pada setiap tanaman inang yang diserang. Pada tomat, biasanya timbul gejala mosaik pada daun, penggulungan daun, reduksi lamina daun, dan tanaman menjadi kerdil (stunt) (Chupp, et al., 1960).

Beberapa varietas tomat yang dianggap tahan serangan CMV oleh petani tomat, telah melalui uji ketahanan benih terhadap CMV yang dilakukan oleh perusahaan - perusahaan produsen benih tersebut. Dari beberapa varietas tomat tersebut, dipilih tiga varietas tomat, yaitu Marta F1, Vicarrio, dan San Marino, untuk diuji kembali ketahanannya terhadap serangan CMV dan mengetahui kebenaran hasil uji ketahanan benih yang dilakukan oleh produsen benih-benih tersebut.

Metode penularan virus secara mekanik dapat digunakan untuk menguji sensitifitas benih terhadap serangan CMV. Varietas yang sensitif terhadap serangan virus ini akan menunjukkan gejala tertular CMV. Beberapa metode pengujian telah dilakukan untuk menguji keberadaan CMV pada tanaman, salah satunya adalah metode DAS-ELISA (Double Antibody Sandwich - Enzyme Linked Immunosorbent Assays). Metode ini digunakan karena proses pengujiannya yang mudah, relatif murah bila dibandingkan dengan biomolekuler (PCR), dan memiliki sensitifitas yang cukup tinggi sampai dengan konsentrasi virus $1-10 \mathrm{ng} / \mathrm{ml}$.

\section{TUJUAN PENELITIAN}

Penelitian ini bertujuan untuk menguji varietas tomat yang tahan terhadap serangan virus CMV, agar didapatkan informasi tentang varietas tomat yang bermutu baik dan tahan terhadap CMV.

\section{BAHAN DAN ALAT}

\section{Bahan}

Bahan - bahan yang digunakan dalam penelitian ini diantaranya adalah isolat CMV (didapatkan dari tanaman yang positif terserang CMV), kontrol positif CMV (AGDIA), tanaman tomat varietas Marta F1, Viccario, dan San Marino, antisera CMV (AGDIA), coating buffer, general extract buffer, enzyme conjugate buffer, substrate buffer, PBST (Phosphate Buffer Saline-Tween) buffer, tablet paraNitrophenylphosphate/pNPP (Agdia), pupuk kandang, tanah steril, karborundum (BDH Chem), larutan dapar fosfat $\mathrm{pH} 7$ 
0,01 M (Merck), kertas towel, dan cotton buds.

Alat

Alat - alat yang digunakan dalam penelitian ini adalah mortar, pistel, pipet mikro (Eppendorf) (ukuran 2-20 $\mu \mathrm{L}, 50$ $100 \mu \mathrm{L}, 1000 \mu \mathrm{L}$, dan $5 \mathrm{~mL}$ ), tip pipet (Axygen) (ukuran 2-20 $\mu \mathrm{L}, 50-100 \mu \mathrm{L}$, $1000 \mu \mathrm{L}$, dan $5 \mathrm{~mL}$ ), tabung mikro (Axygen) (ukuran 1,5 mL), microplate (Nunc), pHmeter (Cyberscan), neraca digital (AND), inkubator (Ratek), medicool (Sanyo), immunowasher (BioRad), ELISA reader (Elx800), polybag, kotak perkecambahan, dan alat-alat gelas laboratorium.

\section{METODE PENELITIAN}

Metode penelitian yang dilakukan adalah metode eksperimen sebenarnya. Pengolahan data dilakukan menggunakan Rancangan Acak Lengkap (RAL). Perlakuan terdiri dari 3 (tiga) varietas tomat yang ditulari CMV dan kontrol berupa tanaman tomat sehat, ulangan dilakukan sebanyak 6 (enam) kali. Isolat CMV berasal dari dua sumber, yaitu dari tanaman tomat yang terserang CMV (didapatkan dari lapangan) dan kontrol positif CMV merk AGDIA. Masingmasing isolat CMV ini ditularkan pada tanaman tomat yang berbeda.

\section{Pelaksanaan Penelitian}

\section{Persiapan Media Tanam}

Media tanam terdiri dari campuran tanah steril dan pupuk kandang (1:1), selanjutnya media tanam dimasukkan ke dalam beberapa polybag.

\section{Pembibitan dan Pemeliharaan Tomat}

Benih tomat direndam dalam larutan $\mathrm{NaOCl} \quad 0,5 \%$ selama 10 menit untuk menghilangkan patogen yang terdapat di permukaan benih. Selanjutnya, benih disemaikan di dalam kotak pengecambahan. Benih yang telah berkecambah dipindahkan ke dalam polybag yang telah berisi media tanam. Persemaian dilakukan di dalam rumah kasa dan dilakukan penyiraman setiap hari, benih dipelihara sampai berumur \pm 10 hari.

\section{Penularan CMV}

Tanaman tomat sehat hasil pembibitan yang telah berumur 10 hari diinokulasi dengan CMV. Inokulasi dilakukan pada sore hari, dengan mengoleskan isolat virus CMV dari sap tanaman terinfeksi CMV dan dari kontrol positif CMV (AGDIA) pada daun tomat sehat yang telah ditaburi karborundum. Tanaman yang digunakan sebagai kontrol hanya diinokulasi dengan larutan dapar fosfat $\mathrm{pH} 7,00,01 \mathrm{M}$.

Sap tanaman untuk inokulasi disiapkan dengan cara menggerus daun tanaman sakit dalam $0,01 \mathrm{M}$ buffer fosfat $\mathrm{pH} \quad 7,0$ dengan perbandingan $1: 5$. Tanaman tomat yang telah diinokulasi dibiarkan selama beberapa hari sampai menunjukkan gejala.

Hasil inokulasi diamati dengan memperhatikan periode inkubasi (waktu inokulasi sampai waktu pertama kali timbul gejala), karakteristik gejala pada tanaman, dan tinggi tanaman. Kemudian dilakukan pengujian serologi dengan metode DAS-ELISA.

\section{Pengamatan Gejala pada Tanaman}

Pengamatan ini dilakukan untuk mengetahui gejala-gejala yang muncul pada tanaman tomat sebagai reaksi terhadap serangan CMV yang telah ditularkan. Bagian - bagian yang diamati adalah warna dan bentuk daun, serta tinggi dan bentuk batang.

\section{Pengamatan Tinggi Tanaman}

Parameter ini dilakukan dengan menggunakan penggaris, tinggi tanaman diukur dari mulai pangkal batang hingga puncak tertinggi tanaman. Pengukuran dilakukan setiap minggu setelah inokulasi sampai tanaman menunjukkan gejala tertular CMV. Pengukuran tinggi tanaman 
ini dilakukan untuk mengetahui pengaruh serangan CMV terhadap kondisi fisik tanaman, karena salah satu gejala penyakit ini adalah terjadinya kekerdilan pada tanaman yang terserang.

\section{Pengujian Serologi}

Ketiga varietas tomat yang diinfeksi oleh virus, diuji dengan menggunakan metode DAS-ELISA untuk mengetahui dan memastikan adanya infeksi CMV yang terjadi di dalam sel tanaman tersebut. Pengamatan gejala saja tidak cukup untuk memastikan bahwa suatu tanaman positif terserang CMV, karena gejala penyakit yang ditimbulkan oleh patogen virus hampir sama antara virus yang satu dengan yang lainnya, sehingga diperlukan uji lanjutan seperti uji DAS-ELISA.

\section{Cara kerja DAS-ELISA adalah sebagai berikut :}

1. Lubang microplate diisi dengan 100 $\mathrm{uL}$ antibodi CMV yang telah dilarutkan dalam coating buffer dengan perbandingan 1 : 200. Microplate ditutup dengan plastik penutup supaya suasana di dalam lubang tetap lembab, kemudian diinkubasi pada suhu $27{ }^{\circ} \mathrm{C}$ selama 4 jam.

2. Microplate kemudian dicuci dengan PBST buffer sebanyak 4-8 kali. Kemudian dikeringkan dengan cara dibalik dan ditepuk - tepukan pada permukaan yang telah dialasi kertas towel, dilakukan hingga tidak ada lagi gelembung udara menempel di dinding lubang microplate.

3. Lubang microplate diisi dengan sap tanaman yang telah digerus menggunakan general extract buffer dengan perbandingan $1: 10$ (berat/volume), masing - masing lubang sebanyak $100 \mathrm{uL}$. Kontrol positif dan kontrol negatif dilarutkan di dalam general extract buffer, kemudian dimasukkan ke dalam lubang microplate, masing-masing sebanyak 100 uL. Microplate ditutup, kemudian diinkubasi pada suhu $4{ }^{\circ} \mathrm{C}$ selama 1 malam.

4. Microplate dicuci seperti pada tahap 2.

5. Enzim dilarutkan di dalam enzyme conjugate buffer dengan perbandingan $1: 200$, pembuatan konjugat dilakukan 10 menit sebelum waktu inkubasi berakhir. Microplate diisi dengan 100 uL larutan enzim. Microplate ditutup, kemudian diinkubasi pada suhu ruang selama 2 jam.

6. Microplate dicuci seperti pada tahap 2.

7. Disiapkan larutan substrat dengan melarutkan pNPP tablet kedalam substrate buffer kira- kira 5 menit sebelum waktu inkubasi berakhir dengan perbandingan $1: 5$. Microplate diisi dengan $100 \mathrm{uL}$ larutan pNPP. Microplate ditutup, kemudian diinkubasi pada suhu ruang selama 3060 menit, di dalam kotak gelap. Setelah proses inkubasi selesai, lubang microplate diisi dengan $50 \mu \mathrm{L} \mathrm{NaOH} 3$ $\mathrm{M}$ untuk menghentikan reaksi perubahan warna dari tidak berwarna menjadi kuning.

8. Pembacaan hasil dilakukan menggunakan ELISA reader dengan panjang gelombang $405 \mathrm{~nm}$.

\section{Pengolahan Data}

Rancangan percobaan yang digunakan dalam penelitian ini adalah Rancangan Acak Lengkap (RAL). Data yang diperoleh kemudian diolah dengan analisis sidik ragam (ANSIRA)/analysis of variance (ANOVA) dan dilanjutkan dengan uji berganda Duncan pada taraf uji $5 \%$.

\section{HASIL DAN PEMBAHASAN}

\section{Periode Inkubasi dan Gejala CMV}

Ketiga varietas yang diinokulasi menunjukkan hasil yang berbeda - beda (Tabel 1). Gejala penyakit hanya muncul pada satu varietas tanaman tomat yang diuji, yaitu varietas San Marino. Varietas Marta F1 dan Viccario tidak menunjukkan gejala tertular CMV pada semua bagian tanaman, baik daun dan batang. Pada 
varietas San Marino, gejala muncul pada tanaman yang diinokulasi dengan isolat yang berasal dari sap tanaman positif CMV, daun pertama dan kedua tidak menunjukkan gejala, tetapi daun ketiga mulai menunjukkan gejala tertular CMV. Tanaman yang ditulari dengan isolat yang berasal dari kontrol positif CMV AGDIA tidak menunjukkan gejala terserang CMV.

Menurut Agrios (1997), adanya daun-daun yang tidak menunjukkan gejala pada tanaman yang telah terinfeksi disebabkan karena konsentrasi virus yang rendah pada daun - daun tersebut, atau bahkan daun - daun tersebut tidak mengandung virus. Virus banyak terdapat pada daun - daun yang masih muda, karena daun - daun muda masih banyak menyimpan energi yang cukup bagi proses infeksi dan replikasi virus.

Gejala pada varietas San Marino muncul pertama kali pada daun ketiga yang baru muncul (daun muda). Awalnya, lamina daun mengalami reduksi warna menjadi agak menguning, warna tulang daun menjadi terlihat lebih tua daripada helaian daunnya (Gambar 1), lalu tepi tepi daun melengkung dan mulai menggulung keatas atau kebawah (Gambar 2).

Periode inkubasi dan gejala yang ditimbulkan CMV pada varietas San Marino beragam, tidak semua gejala akibat serangan CMV terdapat pada tanaman tersebut. Menurut Hull (2002), munculnya gejala sangat dipengaruhi oleh konsentrasi virus, faktor lingkungan (intensitas cahaya, suhu, dan kelembaban udara), dan faktor dari dalam tanaman itu sendiri. Gallitelli (1998) menyebutkan bahwa CMV yang menyerang sistem vaskuler dari tanaman yang terinfeksi tidak dapat menahan tekanan pengaruh fisiologis yang disebabkan oleh kelembaban tanah yang tidak konstan.

Keadaan suhu rumah kasa selama periode inkubasi berkisar antara 28,5 $35,5^{\circ} \mathrm{C}$. Keadaan suhu tersebut mendukung bagi infeksi, replikasi, dan penyebaran virus di dalam tanaman. Lucas (1975) menyebutkan bahwa infeksi virus akan terhambat pada suhu $38-40{ }^{\circ} \mathrm{C}$, dan gejala akan menghilang bila suhu di bawah $10^{\circ} \mathrm{C}$.
Isolat yang berasal dari kontrol positif CMV AGDIA tidak menulari semua varietas tomat yang diuji. Kontrol tersebut merupakan isolat CMV yang berasal dari tanaman yang positif terserang CMV, tetapi ekstrak tanaman tersebut sudah mengalami proses pengkristalan oleh produsennya (AGDIA). Seperti yang disebutkan dalam Francki et al. (1979), CMV relatif kurang stabil dalam ekstrak tanaman (sap), serta tidak dapat bertahan pada suhu diatas $70{ }^{\circ} \mathrm{C}$ selama 10 menit. Dalam Siregar (2005) disebutkan titik inaktivasi CMV adalah $50-55{ }^{\circ} \mathrm{C}$, ketahanan sap $2-3$ hari, dan pada $5{ }^{\circ} \mathrm{C}$ virulensi CMV dapat bertahan 5-6 hari. CMV di dalam ekstrak tersebut tidak rusak karena masih dapat menunjukkan perubahan warna jika diuji dengan metode DAS-ELISA, tetapi tingkat virulensinya menjadi sangat rendah, sehingga tidak bisa menulari tanaman lain. Kontrol positif CMV AGDIA ini biasa digunakan sebagai kontrol positif dalam pengujian DASELISA.

\section{Pengamatan Tinggi Tanaman}

Dari ketiga varietas yang diuji, hanya varietas San Marino yang diinokulasi dengan isolat tanaman positif CMV yang menunjukkan gejala kerdil (Gambar 3 dan Gambar 4). Tinggi tanaman sampai umur $7-12$ hari setelah inokulasi masih menunjukkan tinggi yang normal (sama dengan tanaman kontrol), tetapi pada umur 14 hari batang tanaman mulai menunjukkan gejala kerdil, karena laju tinggi tanaman yang terinfeksi berbeda jauh dengan laju tinggi tanaman kontrol (Gambar 5).

Dari gambar 3, dapat dilihat laju pertumbuhan tomat varietas San Marino yang ditulari dengan isolat virus yang berasal dari sap tanaman jauh berbeda dengan laju pertumbuhan tanaman yang ditulari dengan isolat virus asal kontrol positif AGDIA dan tanaman kontrol. Perbedaan laju pertumbuhan ini disebabkan karena adanya patogen virus yang di dalam sel tanaman tersebut. Pada penelitian ini CMV dapat menyebabkan penurunan/reduksi tinggi tanaman pada 
varietas San Marino sebesar 33\% jika dibandingkan dengan tinggi tanaman yang dapat dicapai oleh tanaman kontrol (tanaman sehat). Menurut Siregar (2005), infeksi CMV dapat menyebabkan kekerdilan tanaman hingga $29-56,6 \%$.

CMV dapat menghambat proses fotosintesis dan pertumbuhan tanaman, karena virus menurunkan kadar hormon pertumbuhan dan dapat pula merangsang sintesis zat-zat yang dapat menghambat pertumbuhan tanaman (Agrios, 1997). Menurut Hull (2002), menurunnya laju fotosintesis pada tanaman yang terinfeksi virus disebabkan karena terjadinya penurunan jumlah dan efisiensi klorofil, serta luas permukaan daun.

Tabel 1. Periode Inkubasi dan Jenis Gejala CMV pada Ketiga Varietas Tomat setelah Inokulasi virus.

\begin{tabular}{clcl}
\hline \multirow{2}{*}{ Varietas } & Asal Isolat & $\begin{array}{c}\text { Periode } \\
\text { Inkubasi (hari) }\end{array}$ & \multicolumn{1}{c}{ Gejala } \\
\hline \multirow{3}{*}{ Marta F1 } & Sap tanaman & $1-28$ & Tidak menunjukkan gejala \\
& Sap AGDIA & $1-28$ & Tidak menunjukkan gejala \\
& Kontrol & $1-28$ & Tidak menunjukkan gejala \\
Viccario & Sap tanaman & $1-28$ & Tidak menunjukkan gejala \\
& Sap AGDIA & $1-28$ & Tidak menunjukkan gejala \\
& Kontrol & $1-28$ & Tidak menunjukkan gejala \\
& Sap tanaman & $8-10$ & Daun menggulung \\
& & $14-28$ & Reduksi lamina daun \\
& & $1-28$ & Batang kerdil \\
& Sap AGDIA & $1-28$ & Tidak menunjukkan gejala \\
& Kontrol & &
\end{tabular}
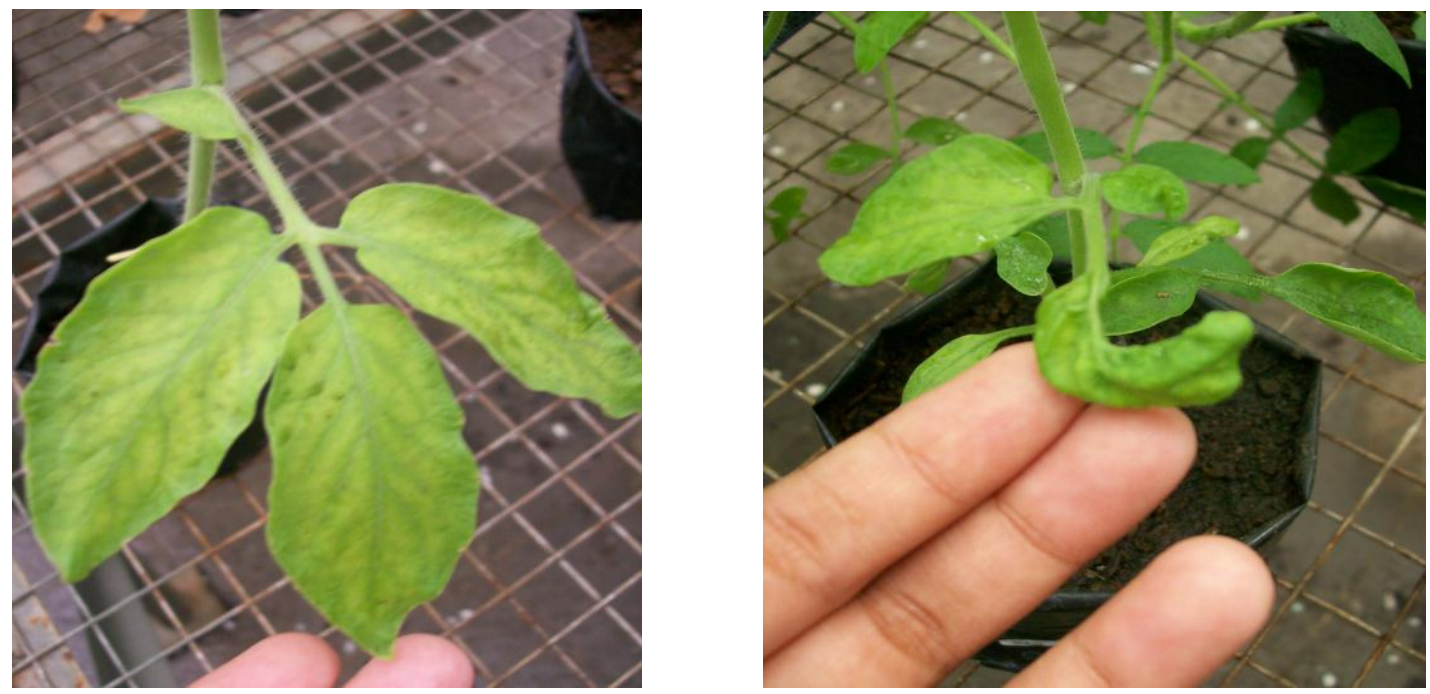

Gambar 1. Gejala Menguning pada Lamina Varietas San Marino Gambar 2. Gejala Menggulung pada Daun Varietas San Marino 


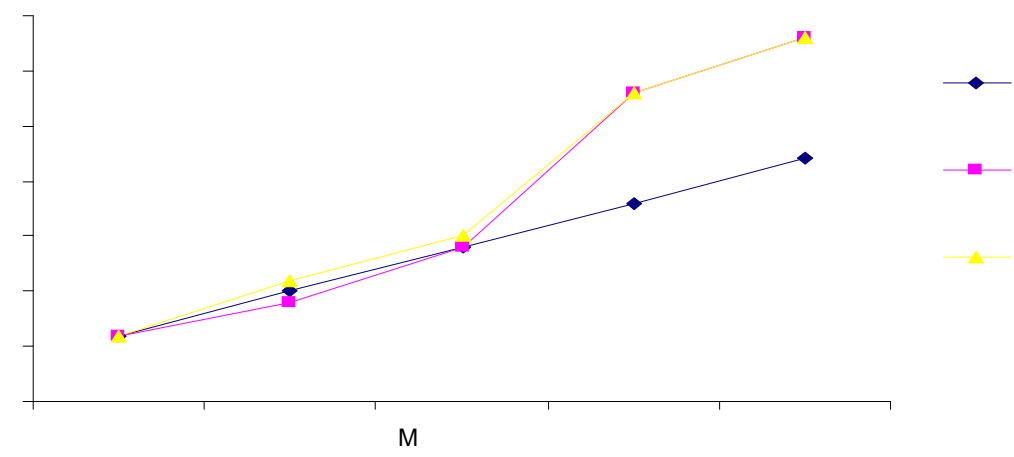

Gambar 3. Grafik Laju Pertumbuhan Tomat Varietas San Marino, Mulai Saat Inokulasi sampai Umur 4 minggu setelah inokulasi.

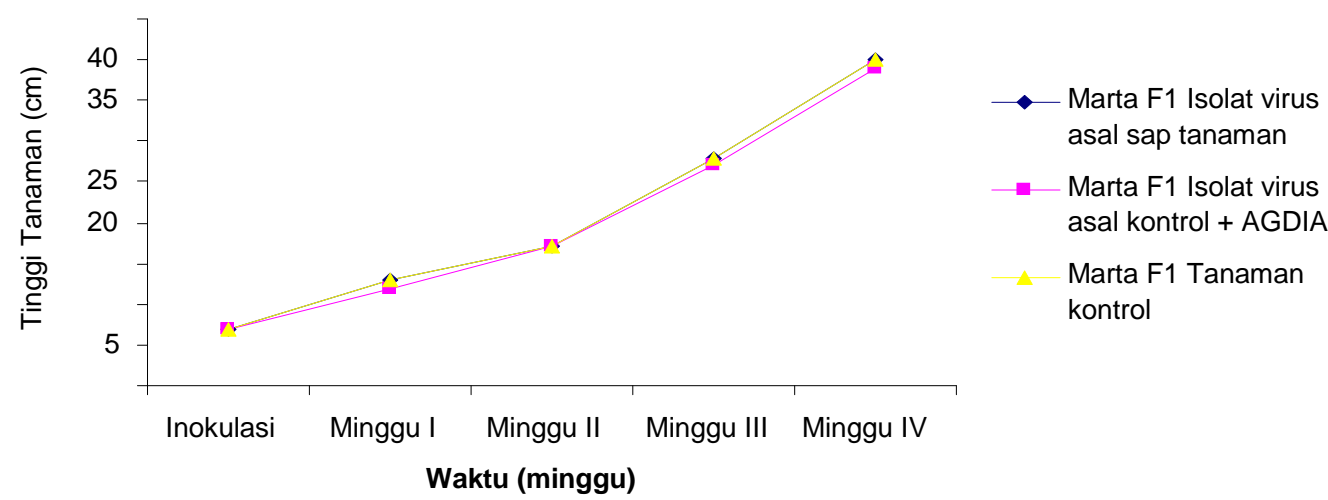

Gambar 4. Grafik Laju Pertumbuhan Tomat Varietas Marta F1, Mulai Saat Inokulasi sampai Umur 4 minggu.

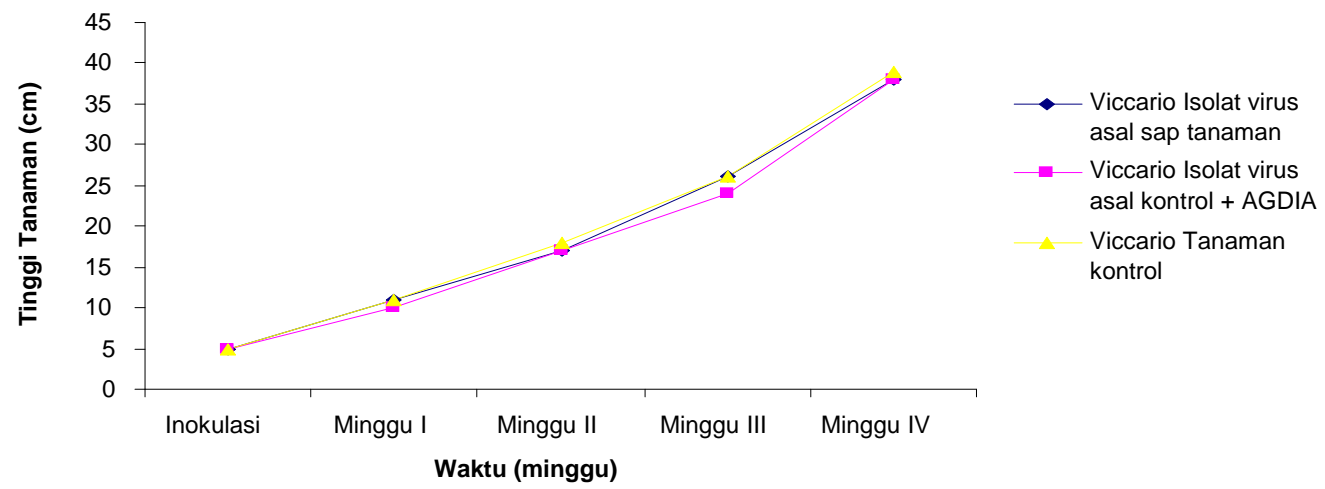

Gambar 5. Grafik Laju Pertumbuhan Tomat Varietas Viccario, Mulai Saat Inokulasi sampai Umur 4 minggu. 
Sinaga (2003) menyebutkan beberapa patogen dapat merusak kloroplasma dan mengurangi klorofil yang dibutuhkan dalam proses fotosintesis, bahkan dapat menghambat pembentukan klorofil sehingga menimbulkan klorosis. Tanaman yang kekurangan hasil fotosintesis akan menjadi kerdil dan mengalami klorosis. Selain itu menurut Hull (2002), laju dan efisiensi fotosintesis yang rendah dapat berakibat pada berkurangnya jumlah karbohidrat yang digunakan untuk perkembangan akar, batang, dan daun. Tanaman yang terinfeksi oleh virus juga mengalami peningkatan respirasi

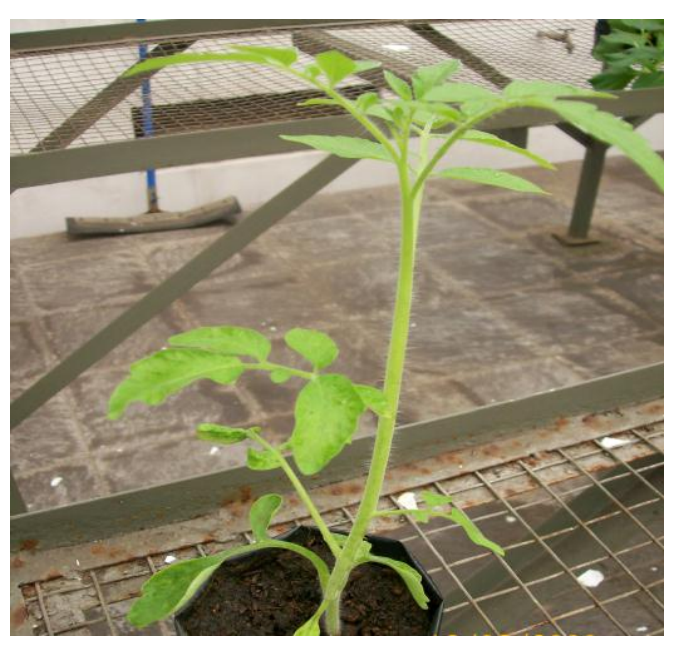

Varietas Marta F1 dan Viccario tidak menunjukkan laju pertumbuhan yang berbeda antara tanaman yang ditulari dengan isolat CMV asal sap tanaman, isolat CMV asal kontrol positif AGDIA, dan tanaman kontrol (Gambar 6 dan Gambar 7). Sifat resisten terhadap serangan CMV yang ada pada varietas Marta F1 telah diakui oleh pemerintah, khususnya Departemen Pertanian yang mengeluarkan surat keputusan Menteri Pertanian No. 256/Kpts/TP.240/2/2002 tentang kualitas benih tomat Marta F1 yang dianggap unggul.

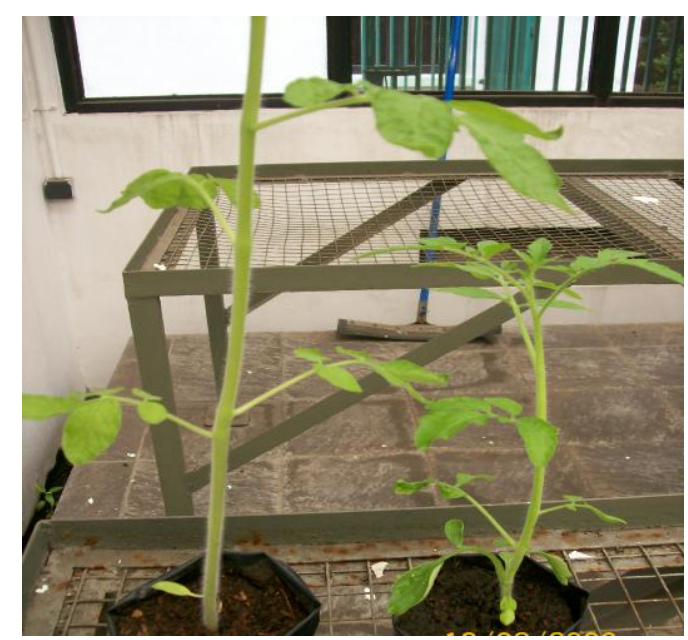

Gambar 6. Varietas San Marino yang mengalami kerdil pada umur yang sama. Gambar 7. Perbandingan San Marino sehat dan kekerdilan (stunt).

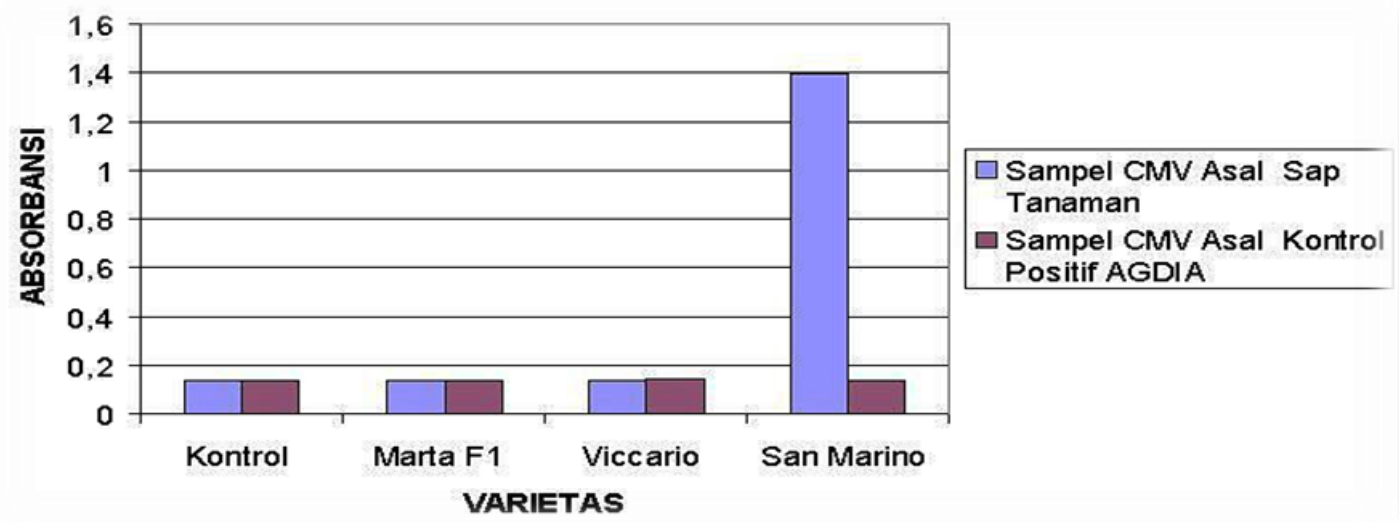

Gambar 8. Grafik Absorbansi DAS-ELISA terhadap Tiga Varietas Tomat yang diuji. 
Pengujian DAS-ELISA Tanaman Tomat

Pengujian DAS-ELISA digunakan sebagai pembuktian secara kuantitatif apabila suatu tanaman menunjukkan gejala terserang virus, CMV dapat diuji menggunakan metode ini. Dari ketiga varietas yang diuji, hanya varietas San Marino yang ditulari virus dari sap tanaman yang menunjukkan perubahan warna menjadi kuning dan nilai absorbansi yang sangat jauh berbeda dengan kontrol (Gambar 11). Hasil ini membuktikan bahwa gejala penyakit yang muncul pada varietas San Marino disebabkan oleh adanya CMV.

Dari gambar 8, dapat dilihat nilai absorbansi yang dihasilkan oleh varietas San Marino yang ditulari CMV asal sap tanaman sangat berbeda nilai absorbansi yang dihasilkan varietas yang lain. Setelah dilakukan uji lanjut Duncan taraf 5\% terhadap nilai-nilai absorbansi tersebut, varietas San Marino yang ditulari CMV asal sap tanaman juga menunjukkan hasil yang berbeda sangat nyata dengan kontrol dan varietas lainnya.

Pengujian terhadap varietas Marta F1 dan Viccario tidak menunjukkan adanya perubahan warna menjadi kuning. Dapat dilihat dari besarnya nilai absorbansi yang tidak lebih dari dua kali lipat kontrol, bahkan tidak jauh berbeda dari nilai absorbansi kontrol. Suatu pengujian dinilai positif apabila nilai absorbansi contoh sebesar dua kali nilai absorbansi kontrol negatif (Dijkstra, 1998).

Tidak munculnya gejala tertular CMV dan hasil uji DAS-ELISA yang negatif terhadap varietas Marta F1 dan Viccario menunjukkan adanya mekanisme ketahanan tanaman terhadap patogen yang menyerangnya. Menurut Russel (1981), ketahanan terhadap infeksi virus secara sistemik dapat disebabkan karena tanaman menghasilkan faktor zat antivirus atau antivirus factor (AVF). Semakin tinggi konsentrasi AVF, maka semakin terbatas penyebaran virus, sehingga mengurangi konsentrasi virus di dalam tanaman, bahkan virus tidak dapat bertahan di dalam tanaman tersebut.
Mekanisme ketahanan awal tanaman terhadap patogen menurut Sinaga (2003) diantaranya adalah mengurangi pembentukan nutrisi yang berguna bagi perkembangan patogen, memproduksi senyawa toksik, dan menghambat pembentukan senyawa esensial yang dibutuhkan patogen. Tanaman juga dapat membuat kondisi yang kurang disukai patogen dalam jaringannya, seperti cekaman air, $\mathrm{pH}$ terlalu tinggi atau rendah, dan kondisi osmotik yang tidak sesuai.

\section{KESIMPULAN DAN SARAN}

\section{Kesimpulan}

Cucumber Mosaic Virus yang menyerang tanaman tomat dapat menunjukkan gejala dan periode inkubasi yang beragam, tergantung ketahanan dari varietas tomat tersebut. Dari ketiga varietas tomat (Marta F1, Viccario, dan San Marino) yang diinokulasi dengan dua sumber isolat (asal sap tanaman dan kontrol positif AGDIA), hanya varietas San Marino yang diinokulasi dengan isolat CMV asal tanaman yang menunjukkan gejala penyakit dan positif terinfeksi CMV setelah dilakukan uji DAS-ELISA.

Varietas Marta F1 merupakan varietas yang dianggap unggul dan direkomendasikan oleh Departemen Pertanian berdasarkan SK Menteri Pertanian No. 256/Kpts/TP.240/2/2002, dan tidak timbulnya gejala akibat infeksi CMV pada varietas ini menunjukkan bahwa varietas Marta F1 memang tahan terhadap infeksi CMV. Belum didapatkan informasi mengenai kualitas benih tomat varietas Viccario yang dikeluarkan oleh Departemen Pertanian, tetapi tidak timbulnya gejala infeksi CMV pada varietas ini juga menunjukkan bahwa varietas Viccario tahan terhadap infeksi CMV.

\section{Saran}

Untuk menghindari kerugian akibat serangan CMV pada perkebunan tomat, petani dapat menggunakan varietas 
Marta F1 dan Viccario yang tahan terhadap infeksi CMV.

Pengujian terhadap varietasvarietas tomat yang lain perlu dilakukan untuk mendapatkan varietas yang tahan terhadap infeksi CMV. Pengujian ketahanan sebaiknya dilanjutkan hingga penentuan persentase tingkat penurunan produksi tanaman akibat serangan CMV.

\section{DAFTAR PUSTAKA}

Agrios, GN. 1997. Plant Pathology. Fourth Edition. Academic Press; New York.

CAB International. 2006. Crop Protection Compendium, 2006 Edition. CAB International; Wallingford, UK.

Chupp, C, and A. F. Sherf. 1960. Vegetables Diseases and Their Control. The Ronald Press Company; New York.

Crowther, JR. 1995. ELISA Theory and Practice. Methods in Molecular Biology, Vol. 42. Humana Press Inc; New Jersey.

Djikstra, J, and C. P. de Jager. 1998. Practical Plant Virology, Protocols and Exercises. Springer Lab Manual; Berlin; Heidelberg; New York.

Doolittle, SP. 1996. A New Infectious Mosaic Disease of Cucumber. Phytopathology 6: p.145 - 147.
Francki, RIB, D. W. Mossop, and T. Hatta. 1979. Cucumber Mosaic Virus. CMI/AAB Descriptions of Plant Viruses, No. 213.

Gallitelli, D. 1998. Present Status of Controlling Cucumber Mosaic Virus. Plant Virus Disease Control, 38. Edited by A. Hadidi, et. al., APS Press; USA.

Heyne, K. 1987. Tumbuhan Berguna Indonesia. Jilid III. Sarana Wana Jaya; Jakarta.

Hull, Roger. 2002. Matthews' Plant Virology. Fourth Edition. Academic Press; New York.

Lucas, GB. 1975. Disease of Tobacco. Harold E, Parker and Sons Printer; North Carolina.

Russel, GE. 1981. Plant Breeding for Pest and Disease Resistance. Butterworth; Toronto.

Sinaga, MS. 2003. Dasar-dasar Ilmu Penyakit Tumbuhan. Penebar Swadaya; Depok.

Siregar, EBM. 2005. Koleksi, Pemurnian, dan Uji Hayati Isolat-isolat CMV Asal Sumatera Utara. Universitas Sumatera Utara. Hal 1-3.

Voyles, BA. 2002. The Biology of Viruses. Second Edition. McGraw-Hill Higher Education; New York. 